Volume 1, Number 1, 2015

\title{
The Estimation of Exergy Efficiency and Exergy Losses in Air Conditioning Systems of Operating Cleanrooms by a Grassmann Diagram
}

\author{
Dmytro Harasym, Volodymyr Labay* \\ Lviv Polytechnic National University, Ukraine, 79013, Lviv, S. Bandery Str., 12 \\ Received: April 10, 2015. Revised: May 13, 2015. Accepted: June 02, 2015.
}

(C) 2015 Authors. Published by Lviv Polytechnic National University.

\begin{abstract}
An important place in the up-to-date technologies related to energy transformation is occupied by the processes and equipment for which the objective value of energy perfection can be defined only on the basis of the thermodynamic analysis. The simplest method of thermodynamic analysis is the energy method based on the law of energy conservation. It provides the possibility to estimate the absolute and relative energy losses and to reveal equipment and processes with the highest losses. However, this method makes the values of all kinds of energy equal, thermal energy in particular, which is wrong according to the second law of thermodynamics, because any kind of energy can be completely converted into thermal energy, while the reverse process is accompanied by unavoidable losses. An innovative mathematical research model of an existing central straight-flow air conditioning system for operating cleanrooms is presented in this article. The aim of the model is to carry out computer estimation of exergy efficiency of existing air conditioning system and exergy losses of its elements depending on different factors affecting its work. The Grassmann diagram of exergy flows and losses for the existing air conditioning system at an outdoor air temperature of $35^{\circ} \mathrm{C}$ has been defined due to this model.
\end{abstract}

Keywords: exergy balance; air conditioning systems; cleanrooms; exergy efficiency; Grassmann diagram.

\section{Introduction}

Nowadays during the exploitation of energy technological systems (ETS), which include air conditioning systems (ACS), to ensure carrying out a certain technology the question of economy of fuel and energy resources is of primary importance. That is why the question of ETS, that can organically combine and complement the requirements of technology and power engineering, is raised now.

In modern technologies, which are related to energy transformation, namely in air conditioning systems, important places are occupied by equipment and processes, the objective estimation of value of whose energy perfection can be defined only on the basis of their thermodynamic analysis. The simplest method of thermodynamic analysis is the energy method based on the law of energy conservation. It allows us to estimate absolute and relative energy losses and to reveal equipment and processes with the highest losses. However, this method equates the values of all kinds of energy, thermal energy in particular, which is wrong according to the second law of thermodynamics, because any kind of energy can be completely converted into thermal energy, while the reverse process is accompanied by unavoidable losses.

Because of of these requirements the exergy method of analysis has been designed in the last decades [3-5]. This method was described in the works of R. Clausisus, J. Gibbs, G. Guye, A. Stodola, Y. Shargut and R. Petela. Its main idea is to introduce, along with the common fundamental concept of energy, an additional indicator - exergy, which allows considering the fact that energy depending on external conditions may have a different value for practical use.

\footnotetext{
* Corresponding author. Email address: wlabay@i.ua
} 
The calculations of balances and different characteristics of ETS, ACS in particular, with the account of exergy enables us to solve many scientific and technical problems in the easiest and clearest way. They help to remove frequent errors that can be found and are connected with the negligence of the qualitative side of transformation.

An important feature of a central straight flow ACS is that the starting substance which is processed in it is the outside air, the parameters of which may vary both in terms of temperature and relative humidity (moisture content and specific enthalpy respectively). As a result of operation ACS provides the required temperature and humidity of supplied and indoor air depending on parameters of outside air. The reduction of energy consumption by ACS dictates the need of its optimization, which can be fully achieved by virtue of exergetic analysis that takes into account not only the quantity, but also the quality of the energy consumed $[3,4,6-8]$.

Exergy balance for the given ETS, i.e. the existing ACS of operating cleanrooms is the following:

$$
E_{\text {in }}=E_{\text {out }}+\sum_{i=1}^{n} D_{i}, \mathrm{~W},
$$

or

$$
\sum_{i=1}^{n} D_{i}=E_{\mathrm{in}}-E_{\mathrm{out}}, \mathrm{W}
$$

where $E_{\text {in }}=E_{\text {ent }}-$ exergy of ACS drive, which is spent on maintaining the process, W; $E_{\text {out }}-$ gain of exergy of air in the air-conditioned room, W; $\sum_{i=1}^{n} D_{i}$ - total exergy losses of ETS, W.

On the basis of exergy balance absolute and relative characteristics of ETS and its separate parts are determined and Grassmann diagram is built, which clearly reflects the flows and losses of exergy in the ETS.

Exergy balance of any ETS is made up on the basis of its basic scheme (Fig. 1).

It is obvious that the perfection of ETS and its elements is higher when exergy losses are lower, and that is why the level of perfection of ETS and its elements is characterized by the so-called exergetic output-input ratio, which is determined on the basis of exergy balance, namely [3-5, 7, 8]:

$$
\eta_{e}=\frac{E_{\mathrm{out}}}{E_{\mathrm{in}}} .
$$

Therefore, the exergetic output-input ratio is determined by the equation (3) and it is not hard to notice that the numerator is useful exergy effect and the denominator - exergy losses, which means that exergetic output-input ratio can be determined by the following equation:

$$
\eta_{e}=\frac{E_{\mathrm{out}}}{E_{\mathrm{out}}+\sum_{i=1}^{n} D_{i}}=\frac{E_{\mathrm{eff}}}{E_{\mathrm{spend}}} .
$$

The Grassmann diagram of exergy flows and losses, which is shown in this article, is very helpful, while carrying out the exergetic analysis of ETS, in our case - the existing central straight flow air conditioning system (ACS) for operating cleanrooms.

\section{Description of the object analyzed and the innovation research model}

The aim of air conditioning is to keep up certain parameters of air in a limited space (in our case, operating cleanrooms). Usually the temperature $t_{\text {in }}$ and relative humidity $\varphi_{\text {in }}$ of air are regulated, but in cleanrooms such a parameter as concentration of dust particles $x_{\text {in }}$ in the air is also regulated $[1,2]$. 
Let us consider the existing central straight flow ACS for operating cleanrooms implemented by the authors and shown in Fig. 1. The work of such a system depends on dominant environmental conditions, i.e. on temperature and moisture content of outdoor air. Therefore, during a warm season the outdoor air is taken via central conditioner through valve 11 , cleaned in filter 10 , then it passes through air heater 9, is politropically cooled and drained in air cooler 8, separated in drops catcher 7 and after that this air is supplied through the air supply filter of conditioner 5 and air supply filters 3 at the entrance of operating cleanrooms via fan unit 6 . The exhaust air of operating cleanrooms is removed from their top and lower zones via extraction system through its valve 17 by extractor fan 18 .

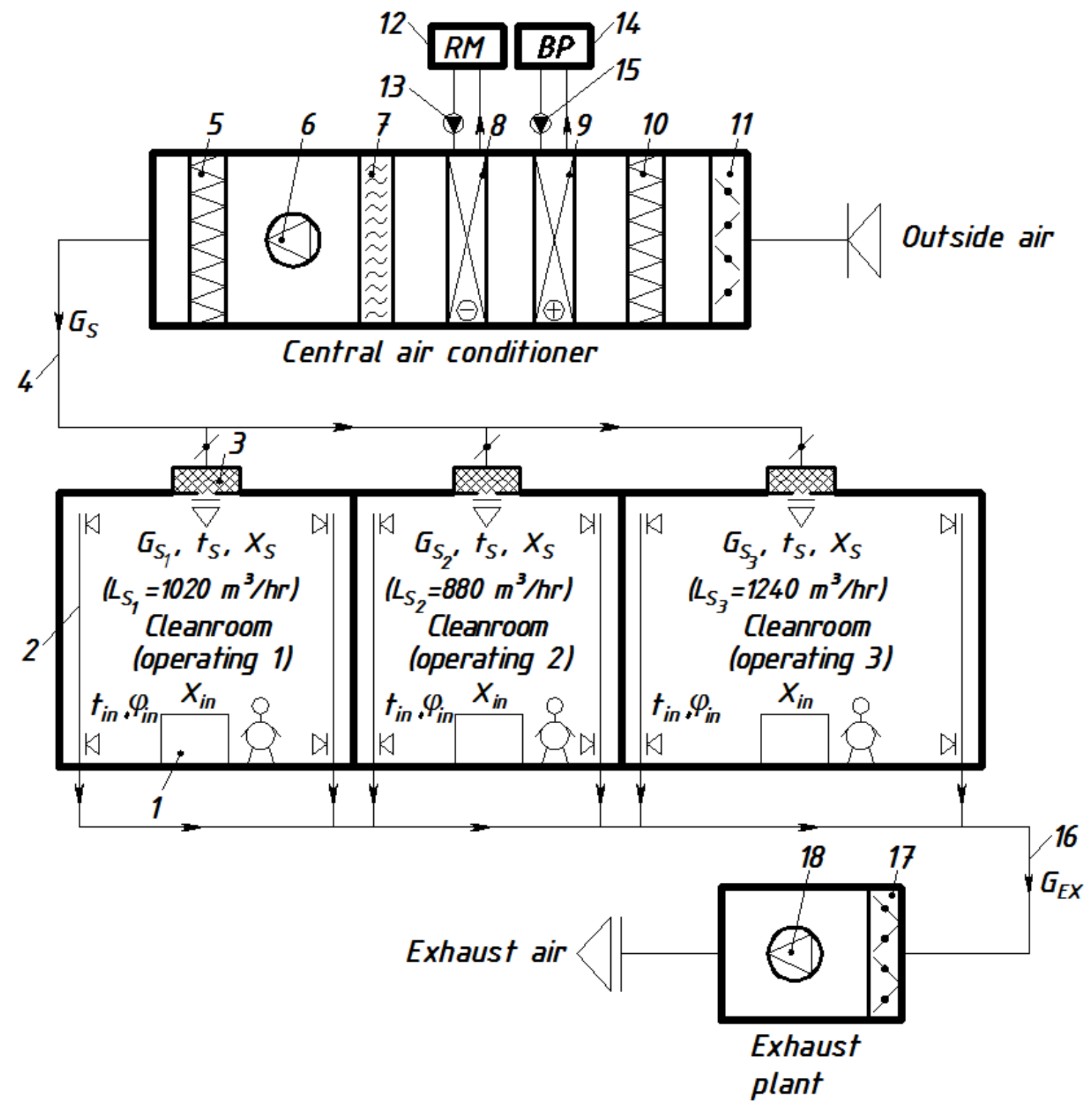

Fig. 1. Basic scheme of the implemented central straight flow ACS of operating cleanrooms: 1 - technological equipment; 2 - air exhaust channels in cleanrooms; 3 - filters of supplied air to the room; 4 - supplied air duct; 5 - filter of supplied air in a conditioner; 6 - fan unit of conditioner; 7 - drop catcher of conditioner; 8 - air cooler of conditioner; 9 - air heater of conditioner; 10 - filter of outside air in conditioner; 11 - valve of outdoor air in conditioner; 12 - refrigerating machine RM; 13 - pump of cold water of RM; 14 - boiler plant BP; 15 - pump of warm water; 16 - exhaust air duct; 17 - valve of exhaust air; 18 - fan unit of the exhaust plant

Let us consider the work of this ACS during a warm season when the temperature $t_{\text {in }}<t_{\text {out }}$. Fig. 2 shows in a coordinate system $I, d$ the sequence of changes of parameters of the air passing through different equipment of the 
implemented central straight flow ACS of operating cleanrooms during a warm season at different parameters of outdoor air. In different studies the mass productivity of the ACS $G=4300 \mathrm{~kg} / \mathrm{hr}$ is accepted, as calculated by the necessary multiplicity of air exchange, the parameters of outdoor air being: temperature $t_{\text {out }}=35{ }^{\circ} \mathrm{C}$; relative humidity $\varphi_{\text {out }}=40 \%$ (specific enthalpy $I_{\text {out }}=71,6 \mathrm{~kJ} / \mathrm{kg}$, moisture content $d_{\text {out }}=14,2 \mathrm{gr} / \mathrm{kg}$, accordingly), barometric pressure $p_{\text {out }}=1010 \mathrm{hPa}$; parameters of indoor air, accordingly $-t_{\text {in }}=27{ }^{\circ} \mathrm{C} ; \varphi_{\text {in }}=60 \%\left(d_{\text {in }}=13,5 \mathrm{hr} / \mathrm{kg}\right.$; $I_{\text {in }}=61,5 \mathrm{~kJ} / \mathrm{kg}$, accordingly; temperature difference between the inside and the supplied air $\Delta t_{S}=t_{\text {in }}-t_{S}=6,0{ }^{\circ} \mathrm{C}$; slope coefficient of excess heat and moisture assimilation in the cleanroom by the supplied air via air conditioner $\varepsilon=16045 \mathrm{~kJ} / \mathrm{kg}$; initial temperature of the coolant (40\% propylene glycol solution) for air cooler $t_{w_{i}}=12,5^{\circ} \mathrm{C}$.

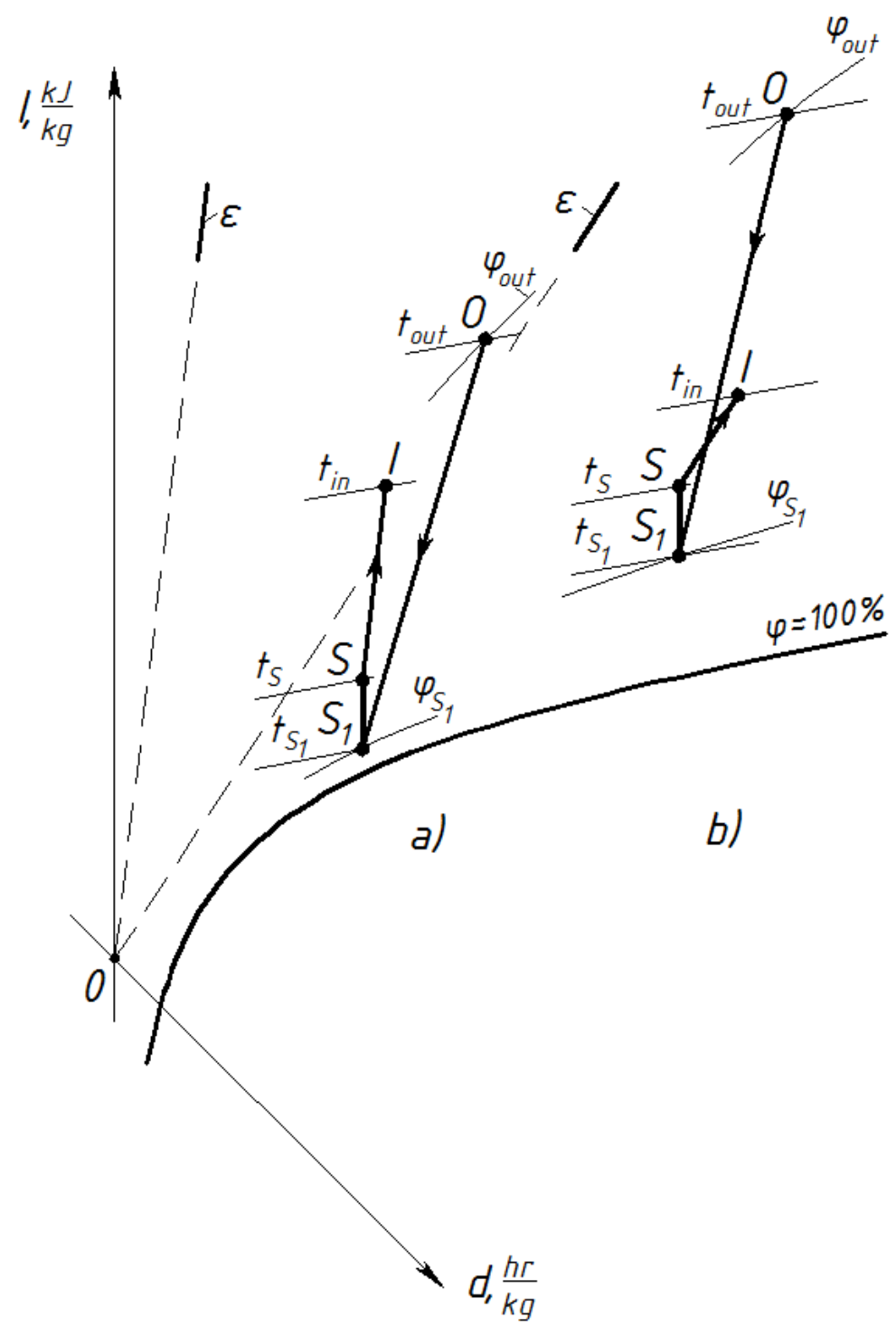

Fig. 2. The process of the changing state of moist air in the implemented central straight flow ACS during a warm season in the $I-d$ - diagram a) for conditions of research $-t_{\text {out }}=30 ; 32{ }^{\circ} \mathrm{C} ; t_{\text {in }}=25 ; 26{ }^{\circ} \mathrm{C}$; $\Delta t_{S}=9 ; 7^{\circ} \mathrm{C} ; \mathrm{b}$ ) for conditions of research $-t_{\text {out }}=\mathbf{3 5} ; 38 ; 40{ }^{\circ} \mathrm{C} ; t_{\text {in }}=27 ; 28 ; 29{ }^{\circ} \mathrm{C} ; \Delta t_{S}=\mathbf{6} ; 5 ; 4{ }^{\circ} \mathrm{C}$ :

$\boldsymbol{O S} \boldsymbol{S}_{\boldsymbol{I}}$ - the process of polytropic treatment (cooling and drying ) of air $G_{\mathrm{out}}=G_{S}$ in the air cooler;

$S_{1} S$ - the process of supplied air $G_{S}$ heating by $1^{\circ} \mathrm{C}$ in a fan and duct;

$\boldsymbol{S I}$ - the process of excess heat and moisture assimilation in a cleanroom by supplied air $G_{S}$ via the conditioner 
The sequences of changes that occur to the moist air passing through various equipment of the implemented ACS are shown in Fig. 2. The $I-d$ - diagram was built in accordance with [6]. Parameters of air in the characteristic points of the process (Fig. 2) were determined by the adopted values of parameters for outdoor air and were calculated using the proposed mathematical model by the known analytical dependences for moist air.

Besides this, the task of the research model - computer estimation of exergy efficiency of the implemented ACS and exergy losses in its elements depending on different factors which affect its work. The Grassmann diagram of exergy flows and losses for the existing ACS at outdoor temperature $35^{\circ} \mathrm{C}$ was determined thanks to this model.

The exergetic output-input ratio, which characterizes the efficiency of the implemented central straight flow ACS of operating cleanrooms during a warm season was determined by equation (4), where $E_{\text {out }}=\Delta E_{\mathrm{SI}}=E_{S}-E_{I}-$ exergy reduction of conditioned air in surgery operating cleanrooms (usefully used exergy), W; $E_{S}$ and $E_{I}-$ respectively, the exergy of supplied and indoor air in the cleanroom, $\mathrm{W} ; D_{\mathrm{AC}}=\Delta E_{\mathrm{OS}_{1}}=E_{S_{1}}-E_{O}-$ exergy losses in the air cooler of conditioner, W; $E_{S_{1}}$ i $E_{O}$ - respectively, the exergy of processed air (outdoor air) at the exit and entrance of the air cooler of conditioner, W; $D_{S_{1} S}=\Delta E_{S_{1} S}=E_{S_{1}}-E_{S}$ - exergy losses during the transportation of air in the supplied fan and ducts of ACS, W; $E_{S_{1}}$ i $E_{S}$ - respectively, the exergy of air at the entrance of supplied fan of conditioner and at the exit of supplied ducts to the cleanrooms, W; $D_{\text {exh }}=\Delta E_{\text {exh }}=E_{I}-E_{O}-$ exergy losses with exhaust conditioned air from the cleanrooms, W; $D_{\text {sup.fan }}=N_{\text {use }}^{\text {sup.fan }}-$ exergy losses in a supplied fan of the conditioner, W; $D_{\text {exh.fan }}=N_{\text {use }}^{\text {exh.fan }}-$ exergy losses in a fan of exhaust plant, W; $D_{\mathrm{RM}}=N_{\text {use }}^{\mathrm{RM}}-$ exergy losses in refrigerating machine for the central conditioner, $\mathrm{W}$.

The values included in the equation (4) for determination of exergetic output-input ratio of the implemented ACS during the warm season were determined as follows:

$$
\Delta E_{\mathrm{SI}}=G_{S} \cdot\left(e_{S}-e_{I}\right) \times 0,278, \mathrm{~W}
$$

where $e_{S}$ i $e_{I}$-respectively, specific exergy of supplied and indoor air in the cleanrooms (Table 1), $\mathrm{kJ} / \mathrm{kg}$;

Table 1. Parameters of points which describe the state of moist air during the work of the implemented air conditioning system at outdoor air temperature $35^{\circ}$

\begin{tabular}{|c|c|c|c|c|c|}
\hline $\begin{array}{c}\text { Points } \\
\text { on the } \\
I-d-\text { diagram }\end{array}$ & $\begin{array}{c}\text { Temperature } \\
t,{ }^{\circ} \mathrm{C}\end{array}$ & $\begin{array}{c}\text { Specific } \\
\text { enthalpy } \\
I, \mathrm{~kJ} / \mathrm{kg}\end{array}$ & $\begin{array}{c}\text { Moisture content } \\
d, \mathrm{hr} / \mathrm{kg}\end{array}$ & $\begin{array}{c}\text { Relative } \\
\text { humidity } \\
\varphi, \%\end{array}$ & $\begin{array}{c}\text { Specific } \\
\text { exergy } \\
e, \mathrm{~kJ} / \mathrm{kg}\end{array}$ \\
\hline \hline $\mathrm{O}$ & 35 & 71,6 & 14,2 & 40 & $0,0-0,0$ \\
\hline $\mathrm{S}_{1}$ & 20 & 53,2 & 13,1 & 89 & 0,3946 \\
\hline $\mathrm{S}$ & 21 & 54,4 & 13,1 & 84 & 0,3437 \\
\hline $\mathrm{I}$ & 27 & 61,5 & 13,5 & 60 & 0,1112 \\
\hline
\end{tabular}

$$
\Delta E_{\mathrm{OS}_{1}}=G_{S}\left(e_{S_{1}}-e_{O}\right) 0,278, \mathrm{~W}
$$

where $e_{O}$ and $e_{S_{1}}$ - respectively, specific exergy of outdoor air and of cooled and drained air in the air cooler, (Table 1), $\mathrm{kJ} / \mathrm{kg}$;

$$
\Delta E_{S_{1} S}=G_{S}\left(e_{S_{1}}-e_{S}\right) 0,278, \mathrm{~W}
$$

де $e_{S}$ - specific exergy at the exit of supplied ducts in the cleanrooms (Table 1), $\mathrm{kJ} / \mathrm{kg}$;

$$
\Delta E_{\text {exh }}=G_{S} \cdot\left(e_{\text {in }}-e_{\text {out }}\right) \times 0,278, \mathrm{~W} .
$$


Using the abovementioned equation we calculated flows and losses of exergy for the implemented ACS at outdoor air temperature $35^{\circ} \mathrm{C}$ during a warm season and made appropriate conclusions.

It should be noted that we did not take into account exergy losses which are related to losses of aerodynamic pressure of air flow, which are slight and could be ignored, and also losses into environment. The parameters which characterize the state of the air at all points of the processes for the given ACS are summarized in Table 1.

\section{Results of the research}

For the construction of a Grassmann diagram let us define exergy losses in the elements of the implemented ACS of operating cleanrooms as a percentage of exergy entrance in the researched ETS.

- in the air cooler cell

$$
D_{\mathrm{AC}}=\frac{\Delta E_{\mathrm{OS}_{1}}}{E_{\text {in }}} 100=3,3 \%
$$

- during the transportation of supplied air in the fan and ducts

$$
D_{S_{1} S}=\frac{\Delta E_{S_{1}} S}{E_{\text {in }}} 100=0,4 \%
$$

- with the supplied fan of conditioner

$$
D_{\text {sup.fan }}=\frac{N_{\text {use }}^{\text {sup.fan }}}{E_{\text {in }}} \cdot 100=18,9 \%
$$

- with the fan of exhaust plant

$$
D_{\text {exh.fan }}=\frac{N_{\text {use }}^{\text {exh.fan }}}{E_{\text {in }}} \cdot 100=10,9 \% \text {; }
$$

- with the refrigerating machine of central conditioner

$$
D_{\mathrm{RM}}=\frac{N_{\mathrm{use}}^{\mathrm{RM}}}{E_{\mathrm{in}}} \cdot 100=63,6 \%
$$

- with exhaust air from cleanrooms

$$
D_{\text {exh }}=\frac{\Delta E_{\text {exh }}}{E_{\text {in }}} \cdot 100=0,9 \%
$$

Let us calculate the usefully used exergy in operating cleanrooms with the ACS as a percentage to the exergy of entrance into the researched ETS:

$$
E_{\mathrm{ROOM}}=\frac{\Delta E_{\mathrm{SI}}}{E_{\text {in }}} \cdot 100=\frac{E_{\text {out }}}{E_{\text {in }}} \cdot 100=1,9 \% .
$$

Then we make up the exergy balance for the Grassmann diagram of the researched ACS of operating cleanrooms for the purpose of appropriate estimation of ETS: 


$$
\begin{aligned}
& E^{+}=E_{\text {in }}=E_{\text {ent }}=D_{\mathrm{AC}}+D_{S_{1} S}+D_{\text {sup.fan }}+ \\
& +D_{\text {exh.fan }}+D_{\mathrm{RM}}+D_{\text {exh }}+E_{\mathrm{ROOM}}=100 .
\end{aligned}
$$

The Grassmann diagram is then built for the researched ETS:

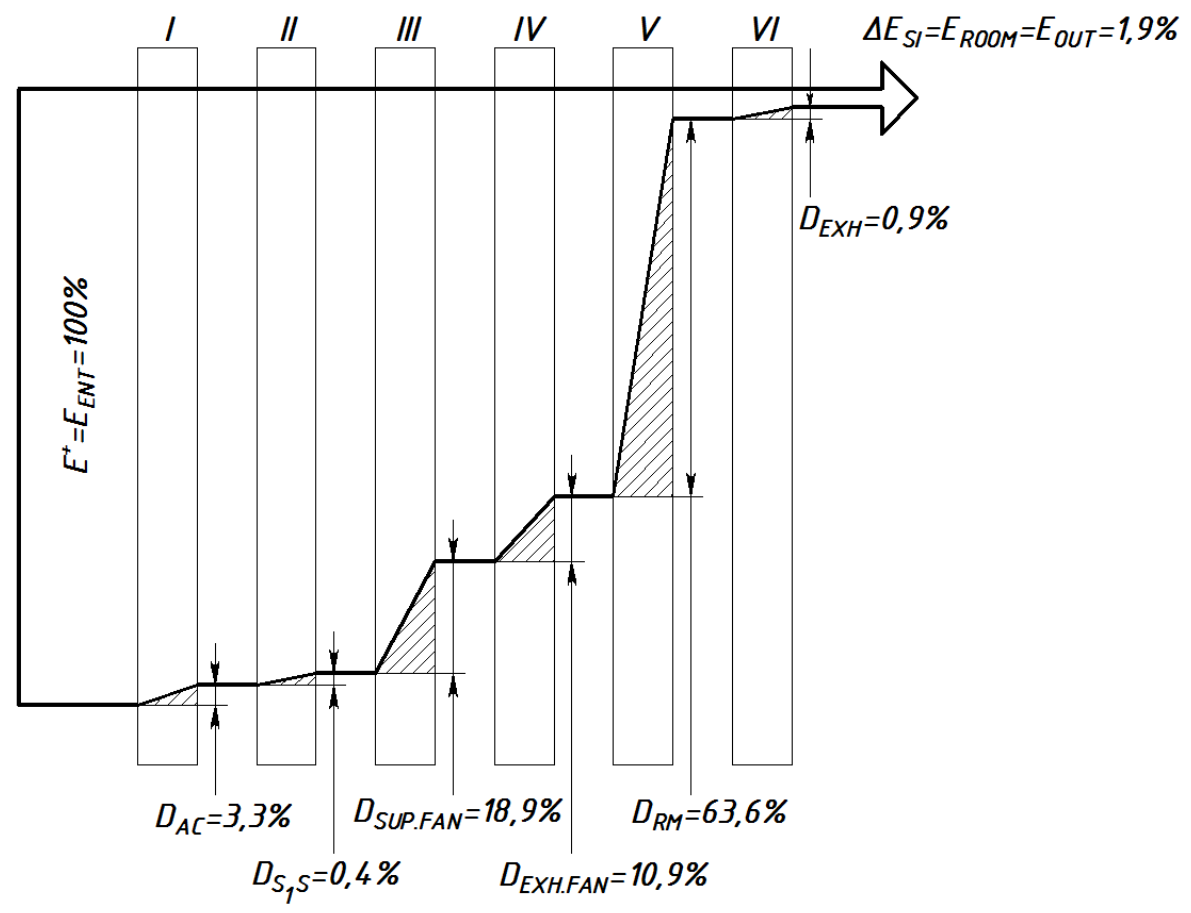

Fig. 3. The Grassmann diagram of exergy flows and losses for the implemented ACS at the temperature of outdoor air $35^{\circ} \mathrm{C}$ : I - air cooler; II - transportation of supplied air in a fan and ducts; III - fan of supplied air of conditioner; IV - fan of exhaust plant; V - refrigerating machine; VI - exhaust air from the cleanrooms

Therefore, the exergetic analysis of the implemented central straight flow ACS of operating cleanrooms which was accomplished on the basis of the authors' innovation mathematical model enables us to build a Grassmann diagram of exergy flows and losses for the existing ACS - in ous case at outdoor air temperature $35^{\circ} \mathrm{C}$.

\section{Conclusions}

Analyzing the obtained research data presented in a Fig. 3 the following conclusions can be reached. To build a Grassmann diagram the innovation mathematical research model of the implemented central straight flow ACS of operating cleanrooms was used. The Grassmann diagram allows computer estimation of exergy efficiency of the existing ACS and exergy losses in its elements depending on different factors affecting its work. The Grassmann diagram of exergy flows and losses for the existing ACS at outdoor air temperature $35{ }^{\circ} \mathrm{C}$ was built thanks to this model, which provides an opportunity to estimate the relative exergy losses in ETS and to understand which kind of losses we should reduce, which means gaining the most advantageous economical variant of exploitation of the implemented ACS. The analysis of the Grassmann diagram for the central straight flow ACS of operating cleanrooms shows that to increase the exergetic output-input ratio of this ETS it is necessary to reduce the exergy losses of the refrigerating machine, the fan transporting the supplied air and the fan transporting extracted air.

\section{References}

[1] Fedotov A. E. Cleanrooms / A. E. Fedotov. $-2^{\text {nd }}$ Ed. - Moskow : ASINKOM, 2003. - 576 p. (in Russian).

[2] Whyte W. Design of cleanrooms. Transl. from English / W. Whyte. - Moskow : Klinrum, 2004. - 360 p. (in Russian).

[3] Shargut Ia. Exergy / Ia. Shargut, R. Petela. - Moskow : Energiia, 1968. - 280 p. (in Russian). 
[4] Exergic design of engineering systems. 1991: hand book / [V. M. Brodianskii, G. P. Verhivker, Ia. Ia. Karchev i dr.] ; ed. A. A. Dolinskii, V. M. Brodianskii; Institute of engineering thermal physics AN USSR. - Kyiv : Nauk. dumka. - 360 p. (in Russian).

[5] Brodianskii V. M. Exergic method of thermo-dynamical analysis / V. M. Brodianskii. - Moskow : Energiia, 1973. - 296 p. (in Russian).

[6] Bogoslovskii V. N. Air conditioning and cooling: Course book for high schools / V. N. Bogoslovskii, O. Ia. Kokorin, L. V. Petrov. Stroiizdat, 1985. - 367 (in Russian).

[7] Labai V. I. Investigation of exergical efficiency of air conditioning systems of cleanrooms / V. I. Labay, D. I. Harasym // Scientific and Engineering Journal "Cooling Engineering and Technology", No 4 (150). - Odessa : ONAKHT, 2014. - P. 47-53. (in Ukrainian).

[8] Labay V. Innovation model for energy effective investigations of air conditioning systems for cleanrooms / V. Labay, D. Harasym // ECONTECHMOD. - Lublin-Rzeszow, 2014 - Vol. 3, № 1. - P. 47-52.

\title{
Оцінювання за діаграмою Грассмана ексергоефективності та втрат ексергії у системі кондиціювання повітря операційних чистих кімнат
}

\author{
Дмитро Гарасим, Володимир Лабай \\ Національний університет “Львівська політехніка”, вул. С. Бандери, 12, Львів, 79013, Украӥна
}

\begin{abstract}
Анотація
У сучасних технологіях, пов'язаних з перетворенням енергії, а саме у СКП, важливе місце займають обладнання і процеси, об’єктивну оцінку ступеня енергетичної досконалості яких можна встановити тільки на основі їх термодинамічного аналізу. Найпростішим методом термодинамічного аналізу є енергетичний, заснований на законі збереження енергії. Він дає змогу оцінити абсолютні і відносні втрати енергії, виявити обладнання і процеси з найбільшими втратами. Однак цей метод прирівнює один до одного цінності всіх видів енергії, зокрема і теплової, що неправильно з позицій другого закону термодинаміки, оскільки будьякий вид енергії може повністю перетворюватись на теплову, зворотний же процес супроводжується неминучими втратами. Використано авторську інноваційну математичну дослідницьку модель впровадженої центральної прямотечійної системи кондиціювання повітря операційних чистих кімнат. Мета моделі комп'ютерне оцінювання ексергетичної ефективності діючої системи кондиціювання та втрат ексергії в ії елементах залежно від різних факторів, що впливають на ії роботу. Завдяки цій моделі отримано діаграму Грассмана потоків та втрат ексергії для діючої системи кондиціювання за температури зовнішнього повітря $35^{\circ} \mathrm{C}$.
\end{abstract}

Ключові слова: ексергетичний баланс; системи кондиціювання повітря; чисті кімнати; ексергетична ефективність; діаграма Грассмана. 